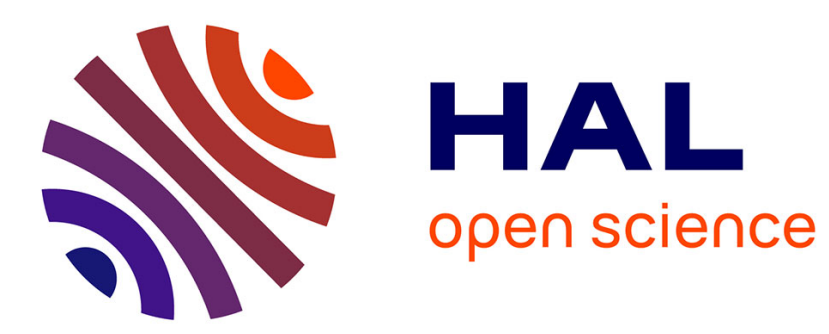

\title{
Bacterial symbiosis in Loripes lucinalis (Mollusca: Bivalvia) with comments on reproductive strategy
}

\author{
M.A. Johnson, Catherine Fernandez
}

\section{To cite this version:}

M.A. Johnson, Catherine Fernandez. Bacterial symbiosis in Loripes lucinalis (Mollusca: Bivalvia) with comments on reproductive strategy. Journal of the Marine Biological Association of the UK, 2001, 81 (02), pp.251-257. 10.1017/S002531540100371X . hal-01768578

\section{HAL Id: hal-01768578 \\ https://hal.science/hal-01768578}

Submitted on 17 Apr 2018

HAL is a multi-disciplinary open access archive for the deposit and dissemination of scientific research documents, whether they are published or not. The documents may come from teaching and research institutions in France or abroad, or from public or private research centers.
L'archive ouverte pluridisciplinaire HAL, est destinée au dépôt et à la diffusion de documents scientifiques de niveau recherche, publiés ou non, émanant des établissements d'enseignement et de recherche français ou étrangers, des laboratoires publics ou privés. 


\title{
Bacterial symbiosis in Loripes lucinalis (Mollusca: Bivalvia) with comments on reproductive strategy
}

\author{
M.A. Johnson* and C. Fernandez \\ EqEL, Faculté des Sciences et Techniques, BP 52, 20250 Corte, France. \\ *Corresponding author, email: Atalarmin@aol.com
}

\begin{abstract}
Loripes lucinalis, a littoral bivalve harbouring endo-cellular sulphur-oxidizing bacteria within its gills, was studied between September 1991 and September 1992 at the Moulin Blanc beach (Brittany, France). The general macro-anatomy of the gill consists of bacteriocyte channels and cylinders made up of two cell types, namely bacteriocytes and intermediate cells. In addition to the usual assortment of cell organelles, the bacteriocytes contain bacterial cells, electron-dense inclusions and large granular bodies. The bacteria are numerous within the bacteriocyte zone, representing $55 \pm 8 \%$ of the gill cross-sectional surface area. Acid phosphatase activity is detectable within the gill tissue both in proximity to and within the bacterial cells. The electron-dense inclusions and large granular bodies also stain positively for acid phosphatase suggesting that these bodies represent different phases of endosymbiont digestion. Bacterial lysis may be an important means of providing L. lucinalis with its nutritional requirements. The granular bodies stain positively for acid polysaccharides and the percentage of the gill cross sectional area occupied by lysed granular zones varied as a function of sampling period. The percentage of total body weight represented by the gill was significantly lower in March compared to September, October and January, all other months being intermediate. The decrease in gill percentages and the levels of gill lysis correspond remarkably well to gamete development.
\end{abstract}

\section{INTRODUCTION}

Symbiotic chemoautotrophic bacteria occur in the tissues of a number of invertebrates where sulphide is present in their environment. These invertebrates include species from five different phyla and from habitats ranging from coastal reducing sediments to deep-sea vents (for reviews see Southward, 1986; Fisher, 1990). Although much literature has appeared since the early eighties which deal with these fascinating relationships, there are still many unanswered questions. Does the host benefit from the symbiosis via direct translocation of bacterially produced metabolites or are the bacteria lysed in order to provide a source of nutrition? Indeed, two paradigms are often used to describe carbon transfer to the host. The first involves what is referred to as 'farming', in which the digestion of the symbionts is used as the main means of nutrient transfer. The second is referred to as 'milking' and involves the translocation of fixed carbon products to the host soon after fixation (Goreau et al., 1973). Another area of controversy concerns whether or not the host can vary its nutritional dependence on the symbiotic bacteria. Obtaining clear answers to these questions is monumental challenge in light of the vast range of organisms that are available for study. There exist, however, an encouraging number of common elements even between phylogenetically dissimilar organisms. It is for this reason that additional descriptive and comparative studies of these bacteria-invertebrate associations are required.
The present study focuses on Loripes lucinalis (Lamarck), a member of the Lucinidae which inhabits reducing sediments and is already known to harbour chemoautotrophic sulphur-oxidizing bacteria within its gill cells (Diouris et al., 1988; Herry et al., 1989; Johnson \& Le Pennec, 1994). Using light microscopy, image analysis, electron microscopy and enzymology, an attempt was made to assess the relationship between the host tissue and the endosymbionts. These data, along with already existing data on L. lucinalis and the Moulin Blanc site (Johnson \& Le Pennec, 1994; Johnson et al., 1994), were used to propose some generalities as to the physiology and biology of these unique organisms.

\section{MATERIALS AND METHODS}

Specimens of Loripes lucinalis were collected monthly from September 1991 to September 1992 inclusive by digging at low tide in the sediment of the Moulin Blanc beach, Brest Harbour (Brittany, France). Live clams were transported to the laboratory, dissected and the different body components weighed after blotting on a paper towel. Samples were then fixed for histological, ultrastructural and enzyme analysis as described below.

\section{Weight of body components}

The gills of between five and eight individuals per month were weighed and expressed as a percentage of total body weight. 


\section{Histology}

Four clams per month were removed from their shells and fixed in aqueous Bouin's solution for $48 \mathrm{~h}$. The samples were then dehydrated in alcohol and embedded in paraffin. Approximately 20 serial sections $(5-\mu$ m thick) were cut per animal and stained with Alcian blue for acidic polysaccharide detection (Gabe, 1968). An additional 20 serial sections were stained using the Masson's trichrome staining method (Gabe, 1968).

\section{Ultrastructure}

Small pieces of gill tissue were fixed in 3\% glutaraldehyde in $0.2 \mathrm{M}$ cacodylate buffer, $\mathrm{pH} 7.5$, adjusted with $\mathrm{NaCl}$ to $1300 \mathrm{mOsm}$ for $24 \mathrm{~h}$ at $4^{\circ} \mathrm{C}$, post-fixed with $2 \%$ osmium tetroxide in the same buffer for $3 \mathrm{~h}\left(4^{\circ} \mathrm{C}\right)$ and embedded in Spurr resin. Semi-thin sections were stained with toluidine blue for light microscopy and ultra-thin sections were stained with $7 \%$ uranyl acetate and $0.1 \%$ lead citrate before examination with a 100CX JEOL microscope.

\section{Enzymology}

Acid phosphatase activity was detected using two different methods. In the first, frozen gill tissue (frozen in 2-methylebutane) was sectioned serially in a cryostat at $-30^{\circ} \mathrm{C}$. Sections were incubated for one hour at $37^{\circ} \mathrm{C}$ in a solution containing $\alpha$ naphthyl phosphate, Walpole buffer and Fast Garnet GBC in the proportions outlined in Gabe (1968) and then examined under light microscopy. For the second method, small pieces of gill tissues were fixed for 1 hour at $4^{\circ} \mathrm{C}$ in $3 \%$ glutaraldehyde in $0.2 \mathrm{M}$ cacodylate buffer adjusted with $\mathrm{NaCl}$ to 1300 mOsm. Following fixation, samples were rinsed overnight in the same buffer, then incubated $30 \mathrm{~min}$ at room temperature in a solution containing $0.05 \mathrm{M}$ acetate buffer ( $\mathrm{pH} 5.4$ ), 0.04 M lead nitrate and $0.01 \mathrm{M} \square$ sodium glycerophosphate. Following this incubation, samples were washed twice in $0.05 \mathrm{M}$ acetate buffer $(\mathrm{pH} 5.4)$ and then in $0.2 \mathrm{M}$ cacodylate buffer. Post-fixation and embedding were performed as described above. For the control samples for both methods, the substrates were omitted from the incubation solutions.

\section{Image analysis}

Image analysis was used to estimate the percentage of the gill cross sectional area in the bacteriocyte region which stained positively for acid polysaccharides as well as the percentage occupied by the endosymbiotic bacteria. For the first estimate, several fields from each histological slide were analysed (minimum of ten gill measurements, maximum of 20) from each individual (four individuals per month). For the second, 25 TEM micrographs were used, originating from 22 ind. The micrographs selected were taken in the bacteriocyte region and represented intermediate cells and non-lysed bacteriocytes. Image analysis was performed by Visilog software (Noesys, France) on a Silicon Graphics (PI 25) computer.

\section{Statistical analyses}

Data were processed by one-way analysis of variance (for analyses over the annual cycle) followed by tests of Tukey (Zar, 1984). Normality and variance homogeneity were verified by Kolmogorov-Smirnov and Bartlett tests, respectively (Zar, 1984). The relationship between acid polysaccharides and percentage oocyte occupancy was assessed using correlation and regression analyses. The software Statgraphics plus (version 1.4) for Windows was used.

\section{RESULTS}

$$
\text { The gill }
$$

The general macro-anatomy of the Loripes lucinalis gill, made up of bacteriocyte cylinders and channels, is identical to that described for several other lucinid clams (Distel \& Felbeck, 1987; Frenkiel \& Mouëza, 1995) (Figure 1A,B). Loripes lucinalis gill tissue is made up of the two cell types classically described in these symbiotic associations, namely bacteriocytes and intermediate cells. The bacteriocytes are large rectangular to spherical cells ranging from 7.6 to $22.5 \mu \mathrm{m}$ in height (average $15.6 \pm 5.9 \mu \mathrm{m}$, mean $\pm \mathrm{SD}$ ) and 7.5 to $19.7 \mu \mathrm{m}$ in diameter (average $13.5 \pm 2.9 \mu \mathrm{m}$, mean $\pm \mathrm{SD}$ ). They have a basal nucleus often irregular in shape (Figure 3 ). The bacteriocytes contain cellular organelles (mitochondria and Golgi bodies) in addition to bacterial cells, electron-dense inclusions and large granular bodies.

\section{Bacteria}

The bacteria are numerous within the bacteriocyte zone and represent $55 \pm 8 \%($ mean $\pm \mathrm{SD})$ of the gill cross sectional area. They are almost exclusively found singly within vacuoles (Figures 3-5). Occasionally, two cells were observed enclosed within the same vacuole. Electron microscopy revealed densely packed glycogen rosettes within the bacterial cytoplasm. In a previous study, the Thiery method (1967) was used to confirm the presence of glycogen within the bacterial symbionts (Herry, 1988). Also present within the bacteria are membrane-bound, clear vacuoles of various sizes believed to be sulphur inclusions (Figure 4).

Acid phosphatase activity, viewed under light microscopy, is observed throughout the gill tissue (Figure 6). Electron-microscopy indicates this activity in proximity to and within the bacterial cells. Enzyme staining appears as a dark halo immediately surrounding the bacterial membrane as well as dark patches within the symbiont cytoplasm (Figure 7). Cells observed apically within the bacteriocytes seem to be the most heavily marked using this technique.

\section{Electron-dense inclusions}

The electron-dense inclusions within the bacteriocytes measure on average $3.9 \pm 1.1 \mu \mathrm{m}$ in diameter (mean $\pm \mathrm{SD}$ ). They exhibit acid phosphatase activity (Figure 6) and are generally located basally within the bacteriocytes. Electron-microscopy reveals that they are made up 

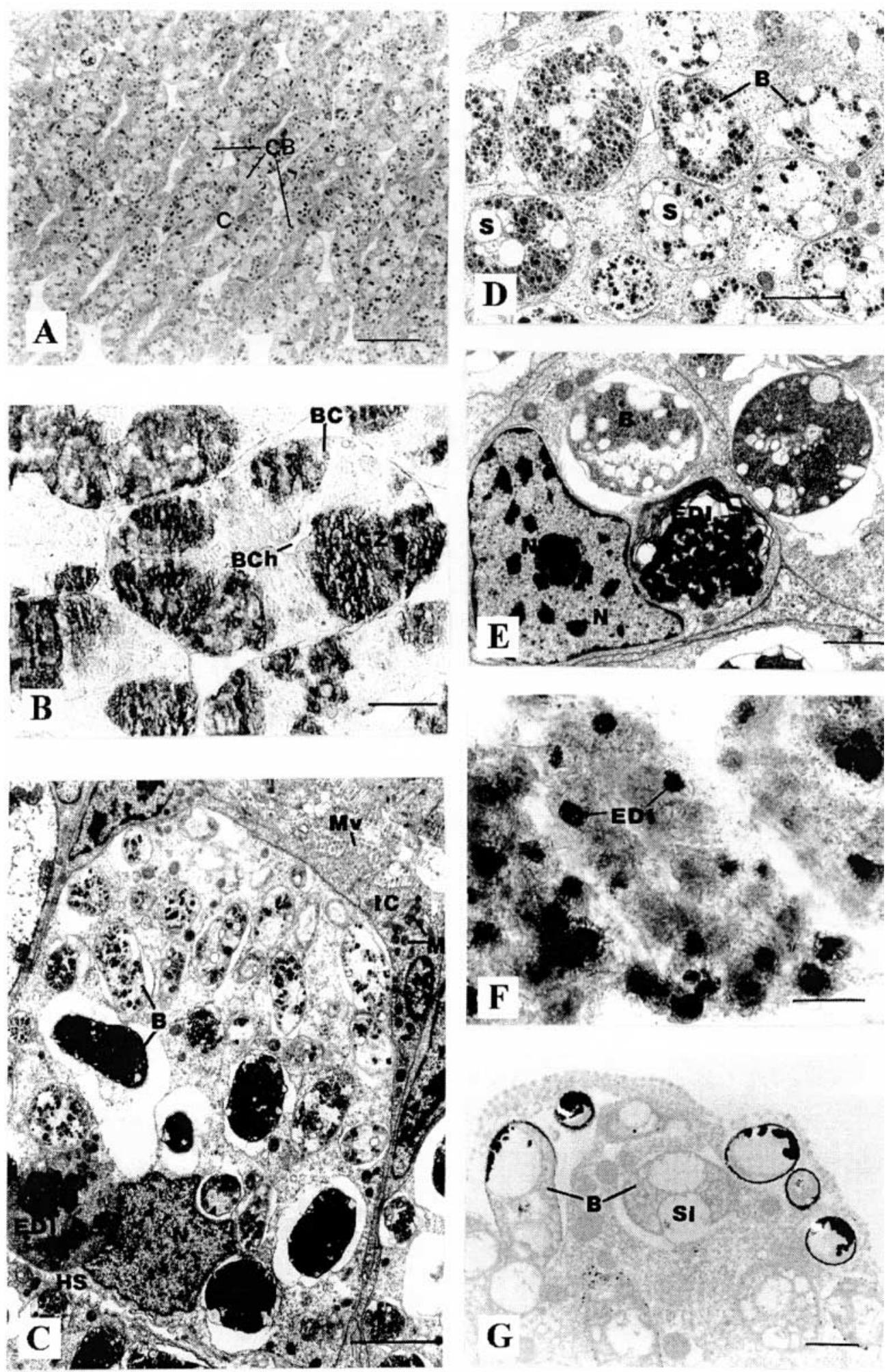

Figure 1. (A) Transversal view of Loripes lucinalis bacteriocyte region showing structural arrangement of bacteriocyte cylinders and channels. Histological section stained with Masson's trichromic staining method and viewed under light microscopy; (B) bacteriocyte cylinder stained with Alcian blue for acid polysaccharide detection (May, 1992 sample). Stained sections represent the granular zones observed under TEM; (C) electron micrograph of a bacteriocyte containing endocellular bacteria and an electron-dense inclusion; (D) electron micrograph of portion of bacteriocyte showing bacteria of various sizes containing glycogen particles and membrane-bound sulphur inclusions; (E) electron micrograph of small bacteriocyte containing a bacteria and an electron-dense inclusion containing myelin-like stands; (F) light microscopy of acid phosphatase activity in gill tissue, as detected by enzymology on frozen tissue sections. Large darkly staining particles are electron-dense inclusions; $(\mathrm{G})$ acid phosphatase activity in the apical portion of a bacteriocyte viewed under transmission electron microscopy. B, bacteria; BC, bacteriocyte; BCc, bacteriocyte cylinder; BCh, bacteriocyte channel; EDI, electron-dense inclusion; GZ, granular zone; HS, hemolymphatic space; IC, intermediate cell; M, mitochondria; Mv, microvilli; N, nucleus; Nc, nucleolus; S, sulphur inclusion. Scale bars: A, $200 \mu \mathrm{m} ;(\mathrm{B} \& \mathrm{~F}), 10 \mu \mathrm{m} ; \mathrm{C}, 5 \mu \mathrm{m} ; \mathrm{D}, 3 \mu \mathrm{m} ;(\mathrm{E} \& \mathrm{G}), 1 \mu \mathrm{m}$. 

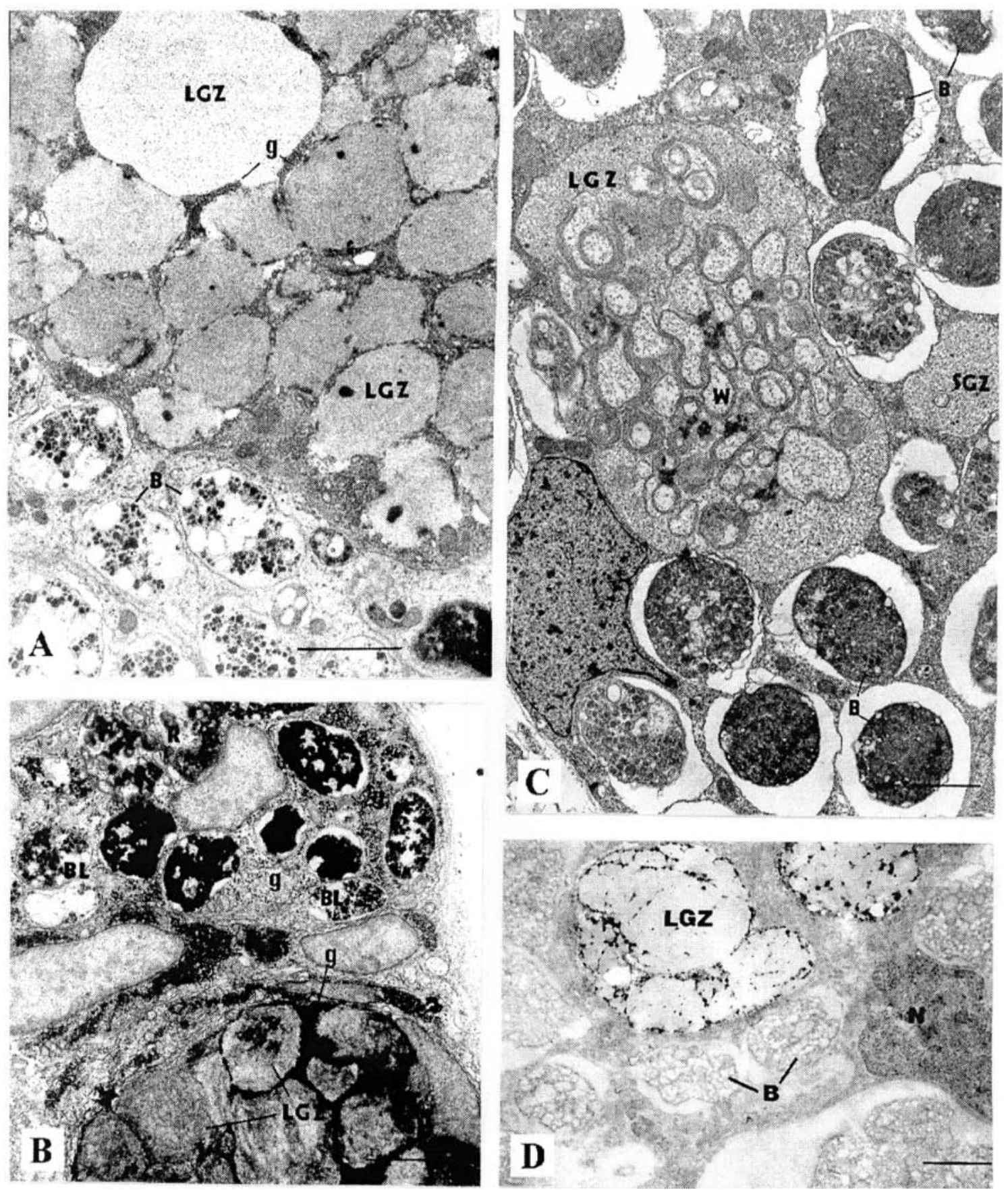

Figure 2. (A) Electron micrograph of portion of bacteriocyte made up of large granular zones which are delimited by densely packed glycogen particles. Neighbouring bacteriocyte (containing bacteria) appears to be intact; (B) electron micrograph representing two bacteriocytes at different stages of degradation. Bacteriocyte in upper half of micrograph is at an intermediate stage and presents remains of electron-dense inclusions and bacteria undergoing lysis. Glycogen particles are numerous within the host cytoplasm. Second bacteriocyte (lower part of micrograph) is in final stage of degradation and is full of large granular bodies surrounded by densely packed glycogen rosettes; $(\mathrm{C})$ electron micrograph of bacteriocyte in an intermediate phase between harbouring an electron-dense inclusion and containing large granular zones; (D) acid phosphatase activity within the granular zone of a gill bacteriocyte viewed under TEM. B, bacteria; BL, bacteria undergoing lytic action; g, glycogen; LGZ, large granular zones; N, nucleus; R, remnant of electron-dense inclusion; SGZ, small granular zone; W, whorls of membrane-like structures. Scale bars: A\&B, $3 \mu \mathrm{m} ; \mathrm{C}, 1 \mu \mathrm{m} ; \mathrm{D}, 2 \mu \mathrm{m}$.

of electron-dense amorphous material as well as membrane-like strands and whorls (Figure 1C\&E).

\section{Large granular bodies}

These numerous granular bodies are ovoid to spherical and measure, on average, $2.7 \pm 0.8 \mu \mathrm{m}$ in width and
$4.1 \pm 1.1 \mu \mathrm{m}$ in length (means $\pm \mathrm{SD}$ ) (Figure $2 \mathrm{~A} \& \mathrm{~B}$ ). They are delimited by densely packed particles which stain positively for glycogen. Intermediate stages in cell degradation were observed. At an early stage, the bacteriocyte appears relatively intact (Figure 2G), while at the following stage, the degree of lysis is more pronounced; some whorls are observed but the majority of the bacteria 


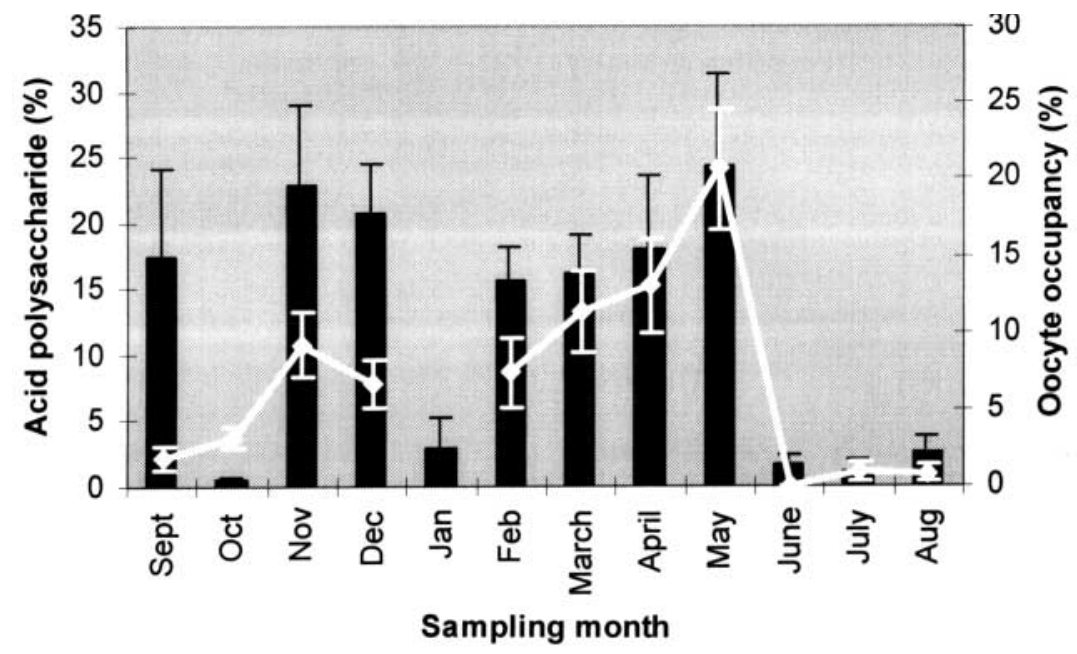

Figure 3. The percentage of Loripes lucinalis gill cross-sectional surface area occupied by lysed granular bodies (mean $\pm \mathrm{SD}$ ), as estimated by acid polysaccharide staining and image analysis techniques, over a one-year period (histogram). Also represented are the mean monthly oocyte occupancy levels $( \pm \mathrm{SD})$ for the same sampling period (line) (taken from Johnson \& Le Pennec, 1994). No oocyte data (ND) are available for the month of January.

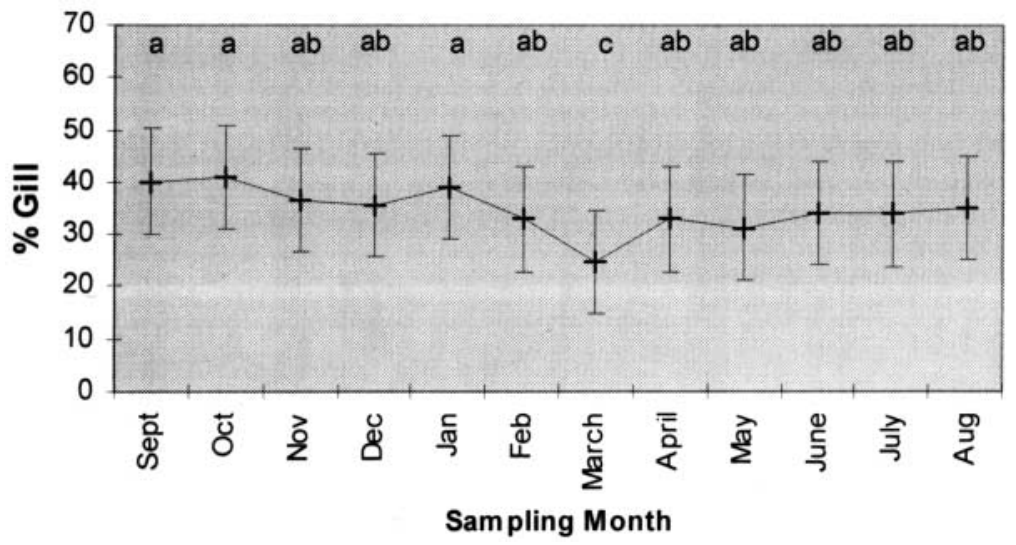

Figure 4. Percentage of Loripes lucinalis total body weight represented by the gill over a one-year sampling period (mean \pm SD). Small case lettering represent the results of a Tukey multiple range test $(P<0.05)$, where 'a' is significantly different from 'c', all other values $(\mathrm{ab})$ being intermediate.

are clearly in the process of degradation with glycogen granules filling the bacteriocyte cytoplasm (Figure 2B). In the final stage of degradation, the bacteriocyte is entirely filled with large granular bodies, which are delimited by densely packed glycogen particles. Acid phosphatase activity was observed within these granular bodies (Figure 2D) and staining with Alcian blue revealed acid polysaccharides, and distinguished between the classical bacteria-containing regions of a bacteriocyte channel and regions made up of granular bodies (Figure 1B). The degree to which the gill tissue stains positively for acid polysaccharides varies between animals and depends on the sampling period. Figure 3 represents the percentage acidpolysaccharide positive areas of the gill cross sectional area. Also represented are the monthly oocyte occupancy levels for the same specimens over the same sampling period which represent the percentage of the gonad occupied by oocytes (taken from Johnson \& Le Pennec, 1994). A significant relationship exists between these two parameters $\left(r^{2}=0.86 ; \mathrm{F}=25.0 ; P<0.001\right)$. The best fit was obtained with a square root-x model and the equation generated was:
$\mathrm{Y}=0.712+6.799$ square $\operatorname{root}(\mathrm{X})$

where $\mathrm{Y}$ is $\%$ acid polysaccharide and $\mathrm{X}$ is percentage oocyte occupancy.

\section{Change in weight of body components}

Gill percentages of total weight varied significantly depending on sampling month (Figure 4; one-way ANOVA, $\mathrm{F}=3.29, P<0.001)$. Notably, the percentage in March was significantly lower than that recorded in September, October and January, all other months being intermediate (Tukey multiple range test, $P<0.05$ ).

\section{DISCUSSION}

The general macro-anatomy of the Loripes lucinalis gill is made up of bacteriocyte cylinders and channels, identical to that described for several other lucinid clams (Distel \& Felbeck, 1987; Frenkiel \& Mouëza, 1995). This anatomical adaptation is extremely beneficial to the host/ symbiont complex as it ensures a constant bathing of the 
bacteriocyte cells by water of the pallial cavity, providing the symbionts with the necessary oxygen and reduced sulphur compounds. The bacteriocytes of L. lucinalis are much like those described in other lucinid bivalve hosts. They measure $15.6 \mu \mathrm{m}$ in height and $13.5 \mu \mathrm{m}$ in width, values similar to those found in other species of Lucinidae (Distel \& Felbeck, 1987; Frenkiel \& Mouëza, 1995; Giere, 1985). The bacteria occupy a large portion of these bacteriocytes. Unlike other studies (Fiala-Médioni \& Métivier, 1986; Distel \& Felbeck, 1987), no clearly dividing bacteria are observed within the bacteriocytes. Bacterial cells are usually found singly within the vacuoles of the bacteriocyte. Occasionally two cells were observed enclosed within the same vacuole which could be the result of cell division or the simultaneous phagocytosis of two bacteria within the same vacuole. Similarly, Frenkiel \& Mouëza (1995) suggested that, although some dividing stages were identified, the increase in bacteriocyte size may be due to endocytosis of an increasing number of bacteria, as the relationships of bacteria with microvillar apical surface of the bacteriocytes suggest.

The symbionts are rod-shaped to oval bacteria measuring $2.1 \mu \mathrm{m}$ in length and $2.9 \mu \mathrm{m}$ in diameter, containing the same types of particles and inclusions as do other such as symbionts. TEM reveals the presence of 2-12 membrane-bound inclusions believed to be sulphur inclusions. Similar sulphur vesicles have been described in a number of chemoautotrophic symbioses (Giere, 1985; Vetter, 1985; Fiala-Médioni \& Métivier, 1986; Southward, 1986; Distel \& Felbeck, 1987; Frenkiel \& Mouëza, 1995).

Electron-dense inclusions are also found within the bacteriocytes principally in the more basal regions of the bacteriocytes. These residual bodies are myelin-like in structure with whorls of membrane-like structures, similar to that described in many other symbioses. They have been called pigment granules (Distel \& Felbeck, 1987), phagocytic vacuoles or phagosomes (Southward, 1986; Le Pennec et al., 1988) and lysozomes (FialaMédioni et al., 1986) but the consensus is that these bodies represent lysed bacteria, a hypothesis that would seem to be supported here based on their general appearance and the fact that they stain positively for acid phosphatase activity. The large granular bodies are also believed to be the result of lytic action within the bacteriocytes but on a much larger scale. Indeed, the electrondense residual bodies are generally few within the cell and do not seem to significantly modify the bacteriocyte's overall structure; the surrounding symbionts appear intact as do the host cellular organelles. However, the large granular bodies fill up the bacteriocyte, seeming to bring about the breakdown of the host cell. Intermediate stages between these two conditions are observed. In the final stage, the remains of lysed bacteria are recognizable as numerous ovoid to spherical granular bodies reminiscent of the intact endocellular bacteria, delimited by densely packed glycogen particles. Similar granular bodies were reported by Fiala-Médioni \& Métivier (1986) for the bivalve Calyptogena magnifica. Marking experiments for the lytic enzyme acid phosphatase reveals that this enzyme is present within L. lucinalis bacteriocytes. Fiala-Médioni et al. (1994) have similarly shown that there are high lysosomal and lysozyme activities in the gill of bivalves from deep hydrothermal vents which the authors related to an active endosymbiont phagocytosis. More recently, Streams et al. (1997) concluded that the cellular equipment necessary for lysosomal digestion of symbionts is present in host bacteriocytes of hydrocarbon seep mussels. TEM in the present study revealed that bacterial lysis can begin as soon as the bacteria are phagocytized since cells at the periphery of the bacteriocytes show acid phosphatase activity. The observation that cells present apically within the bacteriocytes are the most heavily stained is probably due to the staining technique which involves the incubation of pieces of gill tissue. Acid phosphatase activity in frozen tissue sections occurred throughout a given gill area and was not restricted to the apical portion if the bacteriocytes. The large reticulate bodies believed to represent completely lysed bacteria also stained positively.

In the present study, it is suggested that extensive bacterial lysis provides $L$. lucinalis with a large part of its nutritional requirements, although translocation of bacterially produced metabolites may also occur. Simialry, Streams et al. (1997) proposed that host digestion of symbionts occurs and results in carbon transfer from symbionts to the host although translocation could not be ruled out as an additional means of host nutrition.

In the present study, the granular bodies believed to represent degraded bacteria stain positively for acid polysaccharides and are therefore easily differentiated from the intact gill regions. This staining is not surprising since the bulk of the symbionts is made up of glycogen (polymers of glucose units) and the oxidation of glucose produces an acidic sugar (Moore \& Barton, 1978). The percentage of the gill cross sectional surface area occupied by lysed granular bodies varied as a function of sampling period. These percentages are presented in Figure 3 as the percentages of the gonad occupied by female gametes (percentage oocyte occupancy) as described in Johnson \& Le Pennec, 1994. Histological results of this last study suggest that a major spawn occurred in May, leaving the gonad completely empty in June, and a minor spawn between November and December 1991. Classically, spawning in bivalves is indicated by a reduction in the weight of the gonad. This measurement is problematic in L. lucinalis as the gonad and digestive gland are intermingled and cannot be separated. Of interest is the fact that the percentage of total body weight represented by the gill decreased during gametogenesis and spawning (November, December, February, March, April and May). The levels of gill lysis (as estimated by acid polysaccharide staining) correspond remarkably well to gamete development, thus suggesting that the energy for gametogenesis is obtained from the transfer to the oocytes of heterosynthetic metabolites from the endosymbiont-containing tissues. Other factors may influence the lysis of the gill bacteria, including the levels of sediment sulfide. Unpublished data from the Moulin Blanc sampling site, however, indicate that sulfide levels are similar throughout the year at the study site and are thus not a limiting factor. This evidence, notably the evolution in both gill percentages and gill lysis as a function of reproductive effort, albeit circumstantial, is very encouraging and is an advance in our understanding of the general biology of these bivalve-bacteria symbioses. Although histoautoradiographic studies on L. lucinalis 
have already demonstrated that there is a transfer of endosymbiotically fixed carbon to several tissues (Herry et al., 1989) including the gonad (Herry et al., 1990), evidence that the host organism may vary its nutritional input from the symbiotic bacteria has so far been lacking.

\section{REFERENCES}

Diouris, M., Moraga, D., Le Pennec, M., Herry, A. \& Donval, A., 1988. Chimioautotrophie et nutrition chez les Lucinacea, bivalves littoraux de milieux réducteurs. I. Activités enzymatiques des bactéries chimioautotrophes associées aux branchies. Haliotis, Paris, 18, 195-205.

Distel, D.L. \& Felbeck, H., 1987. Endosymbiosis in the lucinid clams Lucinoma aequizonata, Lucinoma annulata and Lucina floridana: a reexamination of the functional morphology of the gills as bacteria-bearing organs. Marine Biology, 96, 79-86.

Fiala-Médioni, A. \& Métivier, C., 1986. Ultrastructure of the gill of the hydrothermal vent bivalve Calyptogena magnifica, with a discussion of its nutrition. Marine Biology, 90, 215-222.

Fiala-Médioni, A., Métivier, G., Herry, A. \& Le Pennec, M., 1986. Ultrastructure of the gill of the hydrothermal vent mytilid Bathymodiolus sp.. Marine Biology, 92, 65-72.

Fiala-Médioni, A., Michalski, J.-C., Jollés, J., Alonso, C. \& Montreuil, J., 1994. Lysosomic and lysozyme activities in the gill of bivalves from deep hydrothermal vents. Compte-rendus de l'Académie des Sciences de Paris, série III, 317, 239-244.

Fisher, C. R., 1990. Chemoautotrophic and methanotrophic symbiosis in marine invertebrates. Reviewes in Aquatic Sciences, 2, 399-436.

Frenkiel, L. \& Mouëza, M., 1995. Gill ultrastructure and symbiotic bacteria in Codakia orbicularis (Bivalvia, Lucinidae). Zoomorphology, 115, 51-61.

Gabe, M., 1968. Techniques histologiques. Paris-VIe: Masson et Cie.

Giere, O., 1985. Structure and position of bacterial endosymbionts in the gill filaments of Lucinidae from Bermuda (Mollusca, Bivalvia). Zoomorphology, 105, 296-301.

Goreau, T.F., Goreau, N.I. \& Yonge, C.M., 1973. On the utilization of photosynthetic products from zooxanthellae and of a dissolved amino acid in Tridacna maxima f. elongata (Mollusca: Bivalvia). Fournal of Zoology, London, 169, 417-454.
Herry, A., 1988. Chimioautotrophie bactérienne dans la branchie de quatre espèces de Lucinacea (Bivalvia). $\mathrm{PhD}$ thesis, University of Brest, France.

Herry, A., Diouris, M. \& Le Pennec, M., 1989. Chemoautotrophic symbionts and translocation of fixed carbon from bacteria to host tissues in the littoral bivalve Loripes lucinalis (Lucinidae). Marine Biology, 101, 305-312.

Herry, A. Diouris, M. \& Le Pennec, M., 1990. Transfert du carbone des bactéries chimioautotrophes intra-branchiales à différents tissus de l'hôte chez Loripes lucinalis (Lucinidae). Société Française de Malacologie, 8ème Congrès National, Brest.

Johnson, M.A., Diouris, M. \& Le Pennec, M., 1994. Endosymbiotic bacterial contribution in the carbon nutrition of Loripes lucinalis (Mollusca: Bivalvia). Symbiosis, 17, 1-3.

Johnson, M.A. \& Le Pennec, M., 1994. The development of the female gamete in the endosymbiont-bearing bivalve Loripes lucinalis. Fournal of the Marine Biological Association of the United Kingdom, 74, 233-242.

Le Pennec, M. Herry, A., Diouris, M., Moraga, D. \& Donval, A., 1988. Chimioautotrophie et nutrition chez les Lucinacea, bivalves littoraux de milieux réducteurs II. Caractéristiques morphologiques des bactéries symbiotiques et modifications structurales adaptives des branchies de l'hôte. Haliotis, 18, 207-217.

Moore, J.A. \& Barton, T.J., 1978. Carbohydrates. In Organic Chemistry: an overview. Philadelphia, USA: W. B. Saunders Company.

Southward, E.C., 1986. Gill symbionts in Thyasirids and other bivalve molluscs. Fournal of the Marine Biological Association of the United Kingdom, 66, 889-914.

Streams, M.E., Fisher, C.R. \& Fiala-Médioni, A., 1997. Methanotrophic symbiont location and fate of carbon incorporated from methane in a hydrocarbon seep mussel. Marine Biology, 129, 465-476.

Thiery, J.P., 1967. Mise en évidence des polysaccharides sur coupes fines en microscopie électronique. Fournal of Microscopie, 6, 987-018.

Vetter, R.D., 1985. Elemental sulfur in the gills of three species of clams containing chemoautotrophic symbiotic bacteria: a possible inorganic energy storage compound. Marine Biology, 88, 33-42.

Submitted 26 Fuly 2000. Accepted 30 Fanuary 2001. 